\title{
EFFECT OF 5 DIFFERENT CAD CAM CORE DESIGNS ON FRACTURE RESISTANCE AND COLOR OF ZIRCONIA BILAYERED CROWNS: AN IN-VITRO STUDY
}

\author{
Mohammad M Rayyan*, Moustafa Aboushelib** and Mariam A. Bdeir ${ }^{* * *}$
}

\begin{abstract}
Objectives: To study influence of different designs of zirconia substructures on color and fracture resistance in bilayered zirconia CAD CAM restorations.

Materials and Methods: Fifty identical PMMA dies were 3D printed using stereolithography, to mimic a prepared maxillary first molar with chamfer finish line of $1 \mathrm{~mm}$, axial reduction of 1.5 $\mathrm{mm}$ and occlusal preparation of $2 \mathrm{~mm}$. CAD CAM (Wieland dental) was used to digitally scan the fifty dies in order to fabricate 50 zirconia copings. They were assigned to 5 groups according to coping design ( $\mathrm{n}=10)$ : Gp FV (control): full-veneer coping covering to finish line, Gp CS: $1 \mathrm{~mm}$ cervical-shoulder, GP BW: monolithic zirconia with window cut-back on the buccal surface, GP $3 \mathrm{~W}$ : monolithic zirconia with window cut-back on buccal, lingual and mesial surfaces and Gp MM: circular projections of $1 \mathrm{~mm}$ on palatal cusps and mid-palatal surface. All copings were then veneered, air-abraded using $50 \mu \mathrm{m}-\mathrm{Al}_{2} \mathrm{O}_{3}$, primed and cemented to their matching dies using resin cement (Rely X U200, 3M-ESPE). Specimens were tagged and thermo-cycled for 10000 cycles. Spectrophotometer (Easy Shade V, VITA Zahnfabrik) was used to digitally analyze the color for all groups. Delta E was calculated in-comparison to the control group. Compressive load was applied to all specimens in the central fossa, parallel to long axis of each die at a crosshead speed of $0.5 \mathrm{~mm} / \mathrm{min}$ till failure. Level of significance between groups was calculated using One Way ANOVA $(\mathrm{P}<0.05)$.
\end{abstract}

Results: Regarding the fracture resistance, a significant difference among groups was revealed by ANOVA(P=0.000). Gp MM recorded the highest mean fracture resistance (2102.3) whereas Gp $3 \mathrm{~W}$ recorded the least (1363.2). Delta E showed no significant difference in color among all tested groups $(\mathrm{P}=.219)$.

Conclusions: Fracture resistance is significantly affected by the core design. MM design increased the mean fracture of Bilayered zirconia without affecting negatively its color, therefore it can be considered as a replacement of the traditional coping design.

KEYWORDS: color, delta E, coping-design, fracture-resistance and zirconia.

* Oral Rehabilitation Sciences Dept., Faculty of Dentistry, Beirut Arab University, Beirut, Lebanon,

** Dental Biomaterials Department, Faculty of Dentistry, Alexandria University, Egypt.

*** Graduate student, Faculty of Dentistry, Lebanese University, Lebanon. 


\section{INTRODUCTION}

In fixed prosthetic dentistry, zirconia-based ceramics have become, framework materials for their chemical stability and excellent mechanical and physical characteristics, in addition to their CAD CAM fabrication technology. In order to get optimal esthetics, zirconia frameworks are veneered with successive layers of ceramic materials that give the definitive restoration superior characteristics mimicking natural dentition. (1) Unfortunately, fracture of veneering layer was the most common problem met in zirconia-based restorations, clinically manifested as chipping or fractures of veneering ceramic, possibly exposing the zirconia framework. (2) Therefore, the prima cause of mechanical failure of bilayered zirconia restorations was fracture of the veneer layer. ${ }^{(3)}$ Hence attempts in finding ways to improve the fracture resistance of zirconia-core restorations while obtaining the best color shades.

Important to state that in addition to the coping design, many factors do have an important impact on the resistance to fractural loads of full ceramic crowns. ${ }^{(4)}$ According to "Scherrer et al., 2006", chips often originate in the wear facets. ${ }^{(3)}$ It is abundantly evident that ceramic crowns strength is highly affected by preparation geometry of crown and especially the cervical shape.(4) Based on fractographic analysis, over tapering of axial walls during tooth preparation subjects the framework to internal circumferential stresses causing its fracture. ${ }^{(5)}$ Both interface and the intensity to build up veneering porcelain without trapping air bubbles, are considered to be important sources of structural troubles. ${ }^{(4)}$ Preparation surface of zirconia framework, type of ceramic veneer and its mode of application, are all variables that influence zirconiaveneer bond-strength. ${ }^{(6)}$ In addition to the treating dentists skills, whether they were prosthodontists, under supervision by prosthodontists, or general practitioners. ${ }^{(16)}$ With regard to laboratory and clinical procedures; milling, occlusal-adjustment, alteration of the intaglio or outer surfaces in order to correct -even microscopic- inconsistencies, are all procedural damages that create surface-flaws which act as stress concentration points, making surfaces vulnerable for cracking and intensely reducing strength and longevity. ${ }^{(1,3)}$ The same dramatic results are also seen when mismatch between coefficients of thermal-expansion between veneer and zirconia exist. In order to improve bonding to the adhesive, intaglio surfaces are roughened by air particle abrasion; however, this process may weaken the crown, making it prone to fracture. ${ }^{(3)}$

Bi-layered restorations are based on the concept of an esthetic material veneering strong core material to combine esthetics and strength. Zirconia cores offered good candidate as core material due to its high strength properties, good opacity and biocompatibility. Numerous reports established veneer chipping to be approximately $15 \%$ after 3-5 years. ${ }^{(4,7,8)}$ Multiple clinical trials, in a review, done on zirconia restorations showed that for low-fusing porcelain, the chipping ranged from $5 \%-25 \%$ at 1 to 5 years. Whereas, for Triceram porcelain on dense zirconia, the chipping reached $54 \%$ after 1 year. ${ }^{(2,9)}$ On another side, minor amounts of chipping problems were also reported. ${ }^{(10,11)}$

Many studies addressed the veneer fracture problem: by changing stabilization component in zirconia ${ }^{(12)}$, cooling rate of veneering ceramics ${ }^{(13)}$, finish line on the preparation itself ${ }^{(5,14)}$, surface treatment on zirconia core before veneering (15), veneering ceramic thickness ${ }^{(16)}$, the use of a zirconiaframework covered by a milled veneer ${ }^{(17,18)}$ and the use of overpressed veneering porcelains. ${ }^{(19)}$

Aboushelib MN, et al, proposed that, compared to press-on veneer-ceramic, found that, double veneer technique have higher bond strength and better interface quality. ${ }^{(6)}$ But Zhang L, et al, found that this technique is the worst in translucency and the least light compared to pressed alone.(1) 
Many authors suggested that design ${ }^{(20-23)}$ and thickness ${ }^{(24)}$ of zirconia framework have influence on the fracture resistance of veneering ceramic. On the other hand, it was suggested by Lorenzoni FC, et al, that core design alteration did not increase the fatigue-life of the PFZ. ${ }^{(25,26)}$

Full-contour monolith zirconia (MZ) ${ }^{(3)}$ solved the veneer-chipping dilemma by simply not using a veneer. The question still rises: can the marriage between monolithic and bilayered zirconia restoration solve the veneer fracture dilemma, where areas of restoration anticipated to be under higher stresses are fabricated entirely from zirconia, while other esthetic areas are bilayered? Can change of core design solve the veneer-chipping problem?

Null hypothesis of current study was that; there would be no significant differences between all coping designs on fracture resistance, nor color.

\section{MATERIALS AND METHODS:}

\section{PMMA die fabrication}

Fifty PMMA upper right maxillary first molar \#16 were 3D printed using stereolithography technology. Having $1.0 \mathrm{~mm}$ heavy chamfer finish line and $2 \mathrm{~mm}$ occlusal reduction with 6-degree convergence angle. With a base of 10X01X20 mm.

\section{Framework fabrication}

PMMAdies were digitally scanned (S50 ZenotecCAD; Wieland Dental) and randomly assigned to the 5 groups according to Coping design $(n=10)$ : Gp FV (control): full-veneer coping covering to finish line, Gp CS: 1 mm cervical-shoulder, GP BW: monolithic zirconia with window cut-back on the buccal surface, GP 3W: monolithic zirconia with window cut-back on buccal, lingual and mesial surfaces and Gp MM: circular projections of $1 \mathrm{~mm}$ on palatal cusps and mid-palatal surface. (Fig.1) CAD models were then milled (Zenotec Select, Wieland dental), cleaned by air blows and water steam then sintered in a ceramic furnace (Zenotec-FireCube, Wieland Dental) using fast-sinter mode for single-unit sintering (cycle time approximately $3 \mathrm{~h}$ ). Copings were steamed, assigned to their corresponding dies and examined for fit under optical light microscope (Nikon MM-200, Nikon Corp).

\section{Veneering procedure}

Adequate quantity of feldspathic ceramic (V9, VitaVM9, Vita-Zahnfabrik) was used to veneer the zirconia copings. The brush technique was used to apply the ceramic slurry to the core ceramic using a slightly oversized vacuum-press index. Absorbent papers were used to remove excess moisture so the ceramic powder will be compacted. All crowns were then fired in ceramic oven (Zenotec Fire Cube, Wieland Dental).

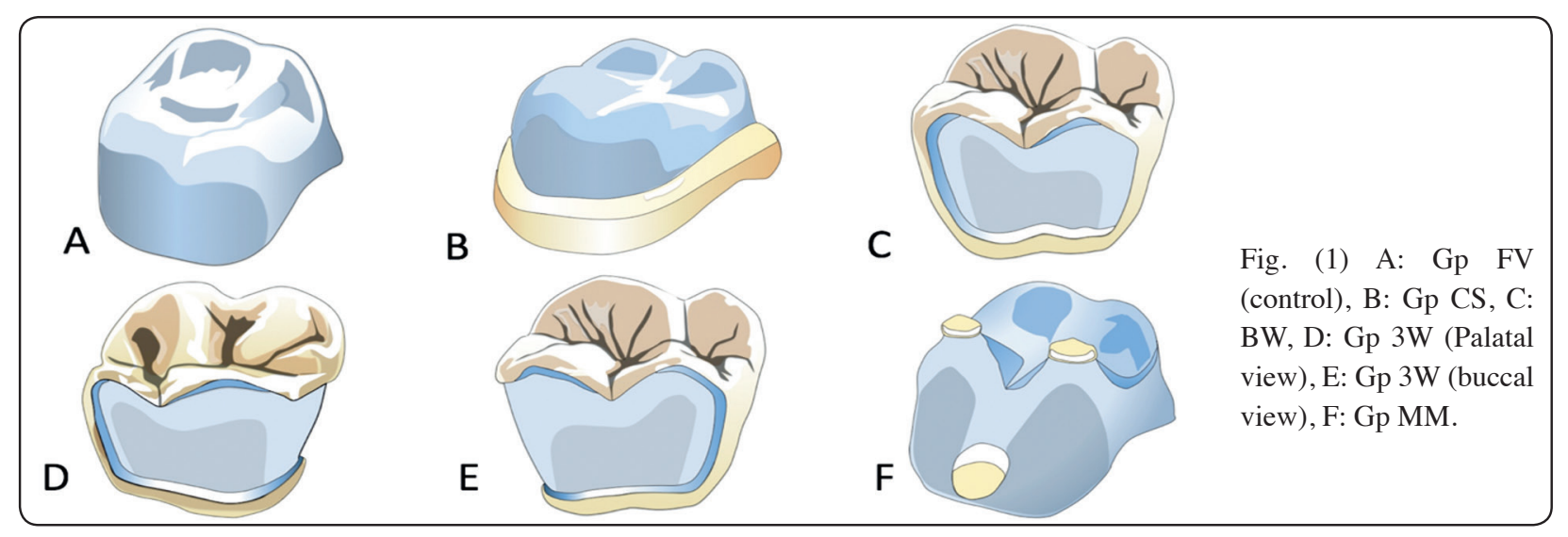




\section{Cementation procedure}

After cooling down, the intaglio surface of all crowns was air-particle abraded using $50 \mu \mathrm{m} \mathrm{Al}_{2} \mathrm{O}_{3}$ at 1.5 pressure bars and at a $2 \mathrm{~cm}$ distance, steamed, primed (3M RelyX Ceramic Primer) and cemented to their matching dies using resin cement (Rely X U200, 3M-ESPE) under $5 \mathrm{~kg}$ static-load for 10 mins. A universal scaler was used to remove excess cement .

\section{Testing procedures}

All specimens were labeled and thermos-cycled for 10000 cycles following sequence of 20 seconds at $55^{\circ} \mathrm{C}$ and 20 seconds at $5^{\circ} \mathrm{C}$ with 10 seconds transport. Specimens were collected and immersed in distilled water at room temperature for $48 \mathrm{hr}$ before testing.

\section{a. Color measurements}

Color measurements were recorded using a digital spectrophotometer (Easy Shade V, VITA Zahnfabrik H). The values CIE-L*a*b* given by the spectrophotometer are mathematical representation of color in 3D space. $\mathrm{L}^{*}$ represents lightness of object being tested, $a^{*}$ value represents color on the red/green axis and $b^{*}$ on yellow/blue axis. Specimens were color measured against standard white-background. Color difference $\left(\Delta \mathrm{E}^{*}\right)$ of each specimen from control group was calculated according to following equation: $\Delta \mathrm{E}^{*}=\left[\left(\mathrm{L}^{*}-\mathrm{L}\right)^{2}+\right.$ $\left.(a *-a)^{2}+(b *-b)^{2}\right]^{1 / 2}$.

\section{b. Facture resistance test}

Computer controlled universal testing machine (LRX plus; Lloyd-Instruments) was used to mount all samples individually with load cell of $5 \mathrm{kN}$. Specimens were mounted in lower member of testing-machine. Compressive load was applied on the central fossa parallel to long axis, using a metallic cylinder rod with round head and radius of $5 \mathrm{~mm}$, attached to the movable compartment of testing-machine traveling at crosshead-speed of 0.5 $\mathrm{mm} / \mathrm{min}$ till fracture, which was defined by sudden drop of load readings. All fracture loads were recorded in Newton.

\section{Data Analysis:}

Recorded data were coded and analyzed using descriptive-statistics (mean and standard deviation) for quantitative variables. Data were found to be normally distributed according to Shapiro-Wilk test. Significant differences between groups were determined using parametric One-Way ANOVA test. Confidence-level of current study was kept as 95.5\%. Therefore, P-values equal or less than .05 were considered statistically-significant.

\section{RESULTS}

Fifty full contoured bi-layered zirconia crowns were divided into 5 groups and tested for fracture resistance and color difference.

Quantitative results between tested groups were demonstrated in Table 2 and chart 1. Regarding mean fracture resistance: MM group scored the highest record of $2102.3 \pm 250.75$, followed by BW group of $1746.9 \pm 169.24$ and the least was $3 \mathrm{~W}$ group; 1363.2 \pm 281.44 . Regarding mean $\triangle \mathrm{E}: \mathrm{MM}$ group scored the least color difference of 1.6 \pm 0.29 , followed by CS group $1.69 \pm 0.26$ and the highest mean color difference was group BW of $1.86 \pm 0.17$. (Table 1, Fig 2and 3)

TABLE (1) Mean \pm SD between tested groups

\begin{tabular}{|c|c|c|}
\hline Group & Facture resistance/ Newton & $\Delta \mathrm{E}$ \\
\hline FV & $1514.2 \pm 201.44$ & $1.77 \pm 0.35$ \\
\hline CS & $1682.9 \pm 323.78$ & $1.69 \pm 0.26$ \\
\hline BW & $1746.9 \pm 169.24$ & $1.86 \pm 0.17$ \\
\hline 3W & $1363.2 \pm 281.44$ & $1.71 \pm 0.21$ \\
\hline MM & $2102.3 \pm 250.75$ & $1.6 \pm 0.29$ \\
\hline
\end{tabular}

SD: standard deviation 


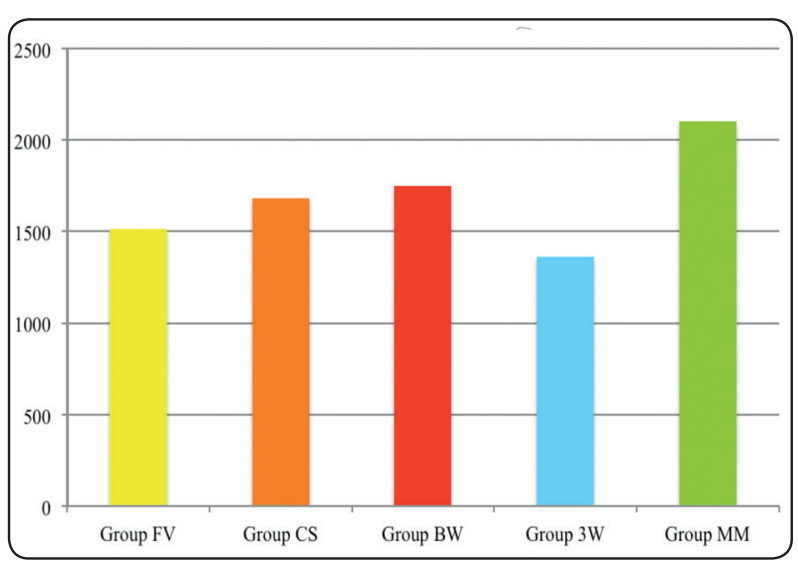

Fig. (2) Means Fracture resistance in Newton

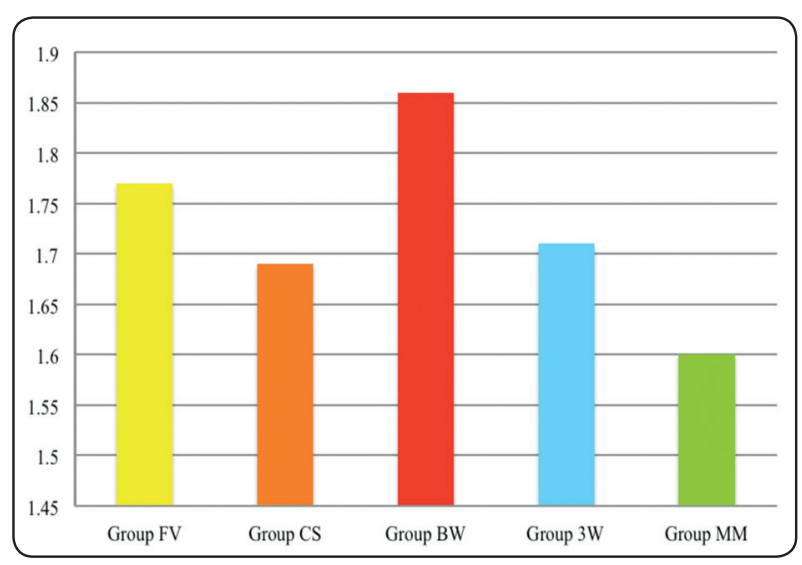

Fig. (3) Means Color difference between groups

For qualitative results, One-Way ANOVA test revealed high significant-difference between the four tested groups $\mathrm{p}<.05$ regarding fracture resistance. One the other hand, no significantdifferences were found between groups regarding color difference, $\mathrm{P}=0.2569$.

\section{DISCUSSION}

After subjecting the samples to 1000 thermocycles and then immersing them in distilled water, the FV design (control group) recorded mean fracture resistance 1514.2 \pm 201.44 . This value increased for group CS to $1682.9 \pm 323.78$ which suggests that the shoulder introduction to the infrastructure improved the ability of crowns to withstand mechanical loads. This coincides with the experimental procedure done by (Seung-Ryong Ha et al., May 2016) ${ }^{(27)}$ where the coping design with no shoulder recorded initial (veneering) fracture load of $4277 \mathrm{~N}$ and bulk fracture load of $4978 \mathrm{~N}$, then these recordings increased till $6259 \mathrm{~N}$ for veneering fracture load and $7680 \mathrm{~N}$ for bulk fracture load for the coping that possessed $2 \mathrm{~mm}$ cervical shoulder. ${ }^{(27)}$ Further resistance to fracture loads was seen in group BW, where this design is full zirconia model with only one buccal window for esthetic purposes, recording $1746.9 \pm 169.24$. This gives a positive feedback for zirconia copings that support a single buccal veneering ceramic from all sides. With demands to improve the mean color difference of group BW which recorded the highest value of $\Delta \mathrm{E} 1.86 \pm 0.17$, a design $3 \mathrm{~W}$ was introduced with 3 windows: buccal, lingual and mesial. Unfortunately, the mean fracture resistance dropped dramatically till 1363.2 \pm 281.44 . Here we have a larger veneering substance subjected to occlusal forces driven through a roof of zirconia that possesses larger flexural strength (MPa) 800 vs 74.6 for feldspathic ceramic (V9, Vita VM9, Vita Zahnfabrik). ${ }^{(28)}$ Based on these values, the veneering ceramic might be unable to absorb the fracture loads of compressive forces received from the capping occlusal table of zirconia. Moreover, chips and fractures of veneering porcelains were assumed develop in areas where the core does not support the veneer, ${ }^{(3)}$ while in this case happens that the stronger zirconia is supported by the weaker veneer. This further supports the results. The highest mean fracture resistance recorded was $2102.3 \pm 250.75$ which belongs to the group MM. This design had circular projections of $1 \mathrm{~mm}$ on the 2 palatal cusps and mid-palatal. During mediotrusive contact, highest stresses were detected in the central groove of the maxillary posterior dentitions whereas during laterotrusive movements, they were observed on the lingual surface of the mandibular-posteriors, ${ }^{(27)}$ which explains the intention of the author in this study to add 2 projections on palatal cusps of the 
upper first molar. The same study done by SeungRyong $\mathrm{Ha}$ et al., showed that when adding $1 \mathrm{~mm}$ to shoulder-height on the lingual-side, the increase in veneer-fracture load was greater than that gained when adding $1 \mathrm{~mm}$ of shoulder-height on the buccal side. (27) This explains the palatal projection in MM group and explains the ability of this coping to withstand the highest loads. However, comparing the vertical loads on a 3-projection coping to the actual, multidirectional, dynamic-functional loading that happens intraorally, makes it difficult to draw a conclusion.

Regarding mean $\Delta \mathrm{E}$; $\mathrm{MM}$ group scored the least color difference of $1.6 \pm 0.29$, which is logical where only 3 projections of zirconia coping are present on the surface. The highest mean color difference was group BW of $1.86 \pm 0.17$ which has only one face of veneering ceramic. These findings appear reasonable. In all cases, no significantdifference was detected between groups regarding color difference, $\mathrm{P}=0.2569$. The null hypothesis regarding fracture resistance was rejected whereas null hypothesis regarding color was accepted.

\section{CONCLUSIONS}

Fracture resistance is significantly affected by the core design. MM design increased the mean fracture of Bilayered zirconia without affecting negatively its color, therefore it can be considered as a replacement of the traditional coping design.

\section{REFERENCES}

1. Zhang L, Luo XP, Shi YJ. Effect of veneering technologies on color and translucency of $\mathrm{Y} 2 \mathrm{O} 3$ stabilized tetragonal zirconia polycrystals all-ceramic restorations. Zhonghua Kou Qiang Yi Xue Za Zhi. 2008 Mar; 43(3):178-81.

2. Al-Amleh B, Lyons K, Swain M. Clinical trials in zirconia: a systematic review. J Oral Rehabil. 2010; 37(8):641-652.

3. Rekow ED, Silvia NR, Coehlo PG, et al. Performance of dental ceramics: challenges for improvements. J Dent Res. 2011;90(8):937-952
4. Vult von Steyern P, Carlson P, Nilner K. All-ceramic fixed partial dentures designed according to the DC-Zirkon technique. A 2-year clinical study. J Oral Rehabil. 2005; 32(3):180-187.

5. Aboushelib MN. Fatigue and fracture resistance of zirconia crowns prepared with different finish line designs. J Prosthodont. 2012 Jan; 21(1):22-7.

6. Aboushelib MN, Kleverlaan CJ, Feilzer AJ. Microtensile bond strength of different components of core veneered all-ceramic restorations. Part 3: double veneer technique. J Prosthodont. 2008 Jan; 17(1):9-13.

7. Sailer I, Fehér A, Filser F, et al. Prospective clinical study of zirconia posterior fixed partial dentures: 3-year followup. Quintessence Int. 2006; 37(9):685-693.

8. Sailer I, Fehér A, Filser F, et al. Five-year clinical results of zirconia frameworks for posterior fixed partial dentures. Int J Prosthodont. 2007; 20(4):383-388.

9. Rothbrust, F, Keutschegger W, Kraxner S, et al. Microstructural effects on the clinical performance of anatomical zirconia [abstract]. J Dent Res. 2011; 90(spec iss A). Abstract 3668

10. Blatz M, Mante F, Chiche G, et al. Clinical survival of posterior zirconia crowns in private practice [abstract]. $\mathrm{J}$ Dent Res. 2010; 89(spec iss B). Abstract 2110.

11. Nathanson D, Chu S, Yamamoto H, et al. Performance of zirconia based crowns and FPDs in prosthodontic practice [abstract]. J Dent Res. 2010; 89(spec iss B). Abstract 2115.

12. Aboushelib MN, Kleverlaan CJ, Feilzer AJ. Evaluation of a high fracture toughness composite ceramic for dental applications. J Prosthodont. 2008 Oct; 17(7):538-44.

13. Mainjot AK, Schajer GS, Vanheusden AJ, Sadoun MJ. Influence of cooling rate on residual stress profile in veneering ceramic: measurement by hole-drilling. Dent Mater. 2011 Sep; 27(9):906-14.

14. Vult von Steyern P. All-ceramic fixed partial dentures. Studies on aluminum oxide- and zirconium dioxide-based ceramic systems. Swed Dent J Suppl. 2005 ; (173):1-69.

15. Chaiyabutr Y,McGowan S, Phillips KM, Kois JC, Giordano RA. The effect of hydrofluoric acid surface treatment and bond strength of a zirconia veneering ceramic. J Prosthet Dent. 2008 Sep; 100(3):194-202.

16. Shirakura A, Lee H, Geminiani A, Ercoli C, Feng C. The influence of veneering porcelain thickness of all-ceramic 
and metal ceramic crowns on failure resistance after cyclic loading. J Prosthet Dent. 2009 Feb; 101(2):119-27.

17. Beuer F, Schweiger J, Eichberger M, Kappert HF, Gernet W, Edelhoff D. High-strength CAD/CAM-fabricated veneering material sintered to zirconia copings--a new fabrication mode for all-ceramic restorations. Dent Mater. 2009 Jan; 25(1):121-8.

18. Aboushelib MN, de Kler M, van der Zel JM, Feilzer AJ. Effect of veneering method on the fracture and bond strength of bilayered zirconia restorations. Int $\mathrm{J}$ Prosthodont. 2008 May-Jun; 21(3):237-40.

19. Stawarczyk B, Ozcan M, Roos M, Trottmann A, Sailer I, Hämmerle $\mathrm{CH}$. Load-bearing capacity and failure types of anterior zirconia crowns veneered with overpressing and layering techniques. Dent Mater. 2011 Oct; 27(10): 1045-53.

20. Aboushelib MN, Kleverlaan CJ, Feilzer AJ. Effect of zirconia type on its bond strength with different veneer ceramics. J Prosthodont. 2008 Jul; 17(5):401-8.

21. Mori K. Influence of the design of zirconia framework on the fracture strength of veneering porcelain. Kokubyo Gakkai Zasshi. 2010 Mar; 77(1):67-70.

22. Larsson C, El Madhoun S, Wennerberg A, Vult von Steyern P. Fracture strength of yttria-stabilized tetragonal zirconia polycrystals crowns with different design: an in vitro study. Clin Oral Implants Res. 2012 Jul;23(7):820-6.
23. Eisenburger M, Mache T, Borchers L, Stiesch M. Fracture stability of anterior zirconia crowns with different core designs and veneered using the layering or the press-over technique. Eur J Oral Sci. 2011 Jun;119(3):253-7.

24. Mainjot AK, Schajer GS, Vanheusden AJ, Sadoun MJ. Influence of zirconia framework thickness on residual stress profile in veneering ceramic: measurement by holedrilling. Dent Mater. 2012 Apr;28(4):378-84.

25. Lorenzoni FC, Martins LM, Silva NR, Coelho PG, Guess PC, Bonfante EA, Thompson VP, Bonfante G. Fatigue life and failure modes of crowns systems with a modified framework design. J Dent. 2010 Aug;38(8):626-34.

26. Brijawi A, Samran A, Samran A, Alqerban A, Murad M. Effect of different core design made of computeraided design/computer-aided manufacturing system and veneering technique on the fracture resistance of zirconia crowns: A laboratory study. J Conserv Dent. 2019 JanFeb;22(1):59-63.

27. Ha SR, Kim SH, Lee JB, Han JS, Yeo IS. Effects of coping designs on fracture modes in zirconia crowns: Progressive load test. Ceramics international. 2016 May 1;42(6): 7380-9.

28. Porto CP, Parente MP, Jorge RM, Pereira LC, Griza S. Fracture toughness of the interface between $\mathrm{Ni}-\mathrm{Cr}$ / ceramic, alumina/ceramic and zirconia/ceramic systems. Fatigue \& Fracture of Engineering Materials \& Structures. 2016 Jul 1;39(7):817-29. 